\title{
PELAKSANAAN TANGGUNG JAWAB SOSIAL PERUSAHAAN PADA PT HKL DITINJAU DARI UNDANG-UNDANG NOMOR 40 TAHUN 2007 TENTANG PERSEROAN TERBATAS
}

\author{
Amanda Rachmi Putri \\ program studi ilmu Hukum Fakultas Syari"ah dan Hukum Universitas Islam \\ Negeri Sultan Syarif Kasim JI. H.R. Soebrantas KM.15 No. 155 Simpang \\ Panam Pekanbaru, Email: Amanda.rachmi.putri@gmail.com
}

\begin{abstract}
Implementation of corporate social responsibility PT. HKL in general has been implemented based on the provisions in Law Number 40 Year 2007 regarding Limited Liability Company as a regulation that covers the obligation of limited liability company in carrying out corporate social responsibility and Riau Province Regulation No. 6 of 2012 on Corporate Social Responsibility as the implementation regulation. However, there are still weaknesses and weaknesses in its implementation based on the provision that there is no education, health, infrastructure, religious, community development programs, and the most important thing is environmental conservation.
\end{abstract}

The factors that become obstacles of PT. HKL in executing corporate social responsibility program is a must wait for approval from directors of companies related to the approval of proposals from the public, unstable production results and tend to decrease will affect the process of corporate social responsibility distribution, the influence of the selling price of PT. $H K L$, and PT. HKL does not have human resources in corporate social responsibility.

Key Words: Implementation, Corporate social responsibility, Limited liability company. 


\section{Abstrak}

Pelaksanaan tanggung jawab sosial perusahaan PT. HKL secara umum sudah dilaksanakan berdasarkan ketentuan yang berlaku dalam UndangUndang Nomor 40 Tahun 2007 tentang Perseroan Terbatas sebagai peraturan yang memayungi kewajiban Perseroan terbatas dalam melaksanakan tanggung jawab sosial perusahaan dan Peraturan Provinsi Riau Nomor 6 Tahun 2012 Tentang Tanggung Jawab Sosial Perusahaan sebagai peraturan pelaksanaannya. Namun masih terdapat kelemahan dan kekurangan dalam pelaksanaanya berdasarkan ketentuannya yaitu, tidak terdapatnya program pendidikan, kesehatan, infrastruktur, keagamaan, pengembangan masyarakat, dan yang paling utama adalah dalam pelestarian lingkungan hidup.

Adapun faktor-faktor yang menjadi hambatan PT. HKL dalam melaksanakan program tanggung jawab sosial perusahaan adalah keharusan menunggu persetujuan dari direksi perusahaan terkait persetujuan proposal dari masyarakat, hasil produksi yang tidak stabil dan cenderung menurun akan mempengaruhi proses penyaluran tanggung jawab sosial perusahaan, pengaruh harga jual hasil produksi PT. HKL, dan PT. HKL tidak memiliki SDM dibidang tanggung jawab sosial perusahaan.

\section{Kata Kunci: Pelaksanaan, tanggungjawab Sosial Perusahaan, perseroan terbatas}

\section{PENDAHULLUAN}

Tanggung Jawab Sosial Perusahaan dapat diartikan sebagai komitmen untuk meningkatkan kesejahteraan komunitas melalui praktik bisnis yang opsional dan melalui sumber daya perusahaan yang dikelolanya. Tanggung Jawab Sosial Perusahaan penting bagi pengembangan perusahaan melalui interaksi perusahaan dengan pemberdayaan masyarakat. Dengan kebijakan yang tepat, perusahaan sebagai industri, dapat mencurahkan perhatiannya kepada proses dan 
pembangunan komunitas yang dapat meningkatkan kesejahteraan masyarakat dengan bersinegi dalam aktifitas bisnis perusahaan. ${ }^{1}$

Pendapat ini sejalan dengan penelitian Matsushita, dalam Basic Management Objective, 1929. Dari hasil penelitiannya, Matsushita menyebutkan bahwa Tanggung Jawab Sosial Perusahaan merupakan bagian yang terinteregasi dari strategi bisnis yang berkelanjutan dan sukses mengatasi masalah sosial dan lingkungan. Sukses bisnis disertai dengan optimisme meningkatkan pendapatan jangka panjang. Tanggung Jawab Sosial Perusahaan merupakan hubungan yang organik antara perusahaan, peningkatan keuntungan dan pembangunan kegiatan sosial. Semakin Organik hubungan yang terjadi, maka semakin menjamin keuntungan jangka panjang perusahaan.Organik menunjukkan bahwa hubungan terjalin secara sistematik dan harmini antara perusahaan dan lingkungan hidup masyarakat. Selanjutnya, dengan memahami kebutuhan masyarakat yang tepat, akan terjaga profit perusahaan jangka panjang. Tanggung Jawab Sosial Perusahaan dapat menjadi instrument manajemen terintegrasi dengan program pemerintah dalam meningkatkan kesejahteraan masyarakat.Kebijakan Tanggung Jawab Sosial yang tepat dapat membangun harmoni komunikasi perusahaan dengan kebijakan pemerintah dan peningkatan kesejahteraan masyarakat. ${ }^{2}$

\section{TINJAUAN PUSTAKA}

\section{A. Perusahaan}

\section{Pengertian Perusahaan}

Perusahaan adalah istilah ekonomi yang dipakai dalam KUHD dan perundang-undangan diluar KUHD. Tetapi dalam KUHD sendiri tidak dijelaskan pengertian resmi istilah perusahaan itu. Rumusan pengertian perusahaan terdapat dalam pasal 1 Undangundang No.3 Tahun 1982 tentang wajib Daftar Perusahaan (

\footnotetext{
${ }^{1}$ Budi Untung, CSR dalam Dunia Bisnis, ( Yogyakarta: Andi Offset, 2014), h. vii - viii.

${ }^{2}$ Ibid., h. xiii.
} 
selanjutnya disingkat UWDP). Dalam pasal 1 huruf (b) Undangundang No.3 Tahun 1982 tentang Wajib Daftar Perusahaan (UWDP), definisi perusahaan adalah sebagai berikut: Perusahaan adalah setiap bentuk usaha yang menjalankan setiap jenis usaha yang bersifat tetap dan terus menerus dan didirikan, bekerja, serta berkedudukan dalam wiayah Negara Indonesia untuk tujuan memperoleh keuntungan dan atau laba. ${ }^{3}$

Berdasarkan ketentuan pasal tersebut diperoleh kenyataan bahwa dalam pengertian perusahaan tersimpul dua hal, yaitu :

a. Bentuk usaha yang berupa organisasi atau badan usaha, dalam bahasa inggris disebut company

b. Jenis usaha yang berupa kegiatan dalam bidang perekonomian yang dilakukan secara terus menerus oleh pengusaha untuk memperoleh keuntungan dan atau laba, dalam bahasa inggris disebut business.

Apabila rumusan ini dibandingkan dengan rumusan Molenggraff dan Polak, ternyata rumusan ini lebih sempurna. Dengan terpenuhi unsur bentuk usaha (badan usaha) dan jenis usaha (kegiatan bidang perekonomian), maka unsur-unsur lain juga terpenuhi. Berdasarkan Undang-undang yang berlaku sekarang, walaupun kegiatan dalam bidang ekonomi dilakukan terusmenerus, terang-terangan, terhadap pihak lain (pihak ketiga), dengan tujuan memperoleh keuntungan dan atau laba, jika tidak dijalanjakan oleh badan usaha, itu bukan perusahaan, melainkan hanya pekerjaan. ${ }^{4}$

\section{Hukum Perushaan}

Hukum Perusahaan mengatur dua kategori hokum, yaitu : (1) hokum yang mengatur bentuk-bentuk perusahaan, dan (2)

\footnotetext{
${ }^{3}$ Abdul Kadir Muhammad, Pengantar Hukum Perusahaan Indonesia, (Bandung: Citra Aditya Bakti, 1993), h. 1

4 Kansil dan Christine S.T.Kansil, Hukum Perusahaan Indonesia, cat ke 2, (Jakarta:Pradnya Paramita, 2001), h. 3
} 
hokum yang mengatur kegiatan usaha. Hokum yang mengatur bentuk-bentuk perusahaan pada umumnya mencakup bentukbentuk usaha persekutuan (partnership) dan bentuk usaha berbadan hokum (corperation). Bentuk usaha persekutuan meliputi bentuk usaha firma, Commanditer Vennotschap (CV). Sedangkan bentuk usaha berbadan hokum meliputi Perseroan Terbatas (PT) dan Koperasi. Bentuk usaha PT pada umumnya membahas tentang PT Biasa, dan PT BUMN. PT Biasa mencakup PT Tertutup dan PT Terbuka. ${ }^{5}$

\section{Bentuk-Bentuk Hukum Badan Usaha}

a) Persekutuan Perdata

Menurut RT.Sutandya R. Hadikusuma dan Sumantoro (1991;13), yang dimaksudkan dengan persekutuan perdata adalah:

"suatu persekutuan yang dibentuk atas suatu perjanjian, dimana dua orang atau lebih mengikatkan diri untuk memasukkan sesuatu (inbreng) kedalam persekutuan dengan maksud untuk membagi keuntungan"6

Berdasarkan pengertian diatas, persekutuan perdata pada intinya mengandung unsur-unsur: ${ }^{7}$

a. Adanya pemasukan sesuatu ke dalam perusahaan, yang dapat berupa:

1. Uang

2. Barang atau benda apa saja yang layak bagi pemasukan misalnya rumah/gedung, perlengkapan kantor, mobil angkutan, dan sebagainya

3. Tenaga, baik fisik atau pikiran.

b. Adanya Pembagian Keuntungan/kemanfaatan:

1. Pembagian harus dilakukan menurut harga atau nilai dari pemasukan masing-masing sekutu

\footnotetext{
5 Agus Sardjono, Pengantar Hukum Dagang, (Jakarta:Raja Grafindo Persada, 2014), h. 25

${ }^{6}$ Zaeni Asyhadie, Hukum Bisnis Prinsip Dan Pelaksanaannya Di Indonesia, Jakarta: Raja Grafindo Persada, 2011), h. 35

${ }^{7}$ Ibid., h. 36
} 
2. Semua sekutu yang hanya memasukkan tenaganya saja, hanya akan mendapatkan keuntungan yang sama rata, kecuali ditentukan lain.

3. Bagi sekutu yang hanya memasukkan tenaganya saja, keuntungannya dipersamakan dengan sekutu yang memasukkan uang atau barang yang terkecil nilainya.

b) Persekutuan Firma

Menurut perumusan pasal 16 dan $18 \mathrm{KUHD}$, yang dimaksudkan dengan persero firma adalah tiap-tiap perseroan (maatschap) yang didirikan untuk menjalankan sesuatu perusahaan dibawah satu nama bersama, dimana anggotaanggotanya langsung dan sendiri-sendiri bertanggung jawab sepenuhnya terhadap orang- orang pihak ketiga. Perkataan firma (fa) sebenarnya berarti nama yang dipakai untuk berdagang bersama-sama. Nama suatu firma adakalanya diambil dari nama seorang yang turut menjadi persero pada firma itu sendiri, tetapi dapat juga nama itu diambil dari nama orang yang bukan persero. Dengan nama bersama itu juga dipakai untuk menandatangani surat menyurat perusahaan. ${ }^{8}$

c) Persekutuan Komanditer (CV)

Pasal 19 KUHD menyebutkan bahwa perseroan komanditer atau CV (commanditer vennootschap) adalah suatu perseroan untuk menjalankan suatu perusahaan yang dibentuk antara satu orang atau beberapa orang persero yang secara tanggung menanggung bertanggung jawab untuk seluruhnya (Tanggung Jawab Solider) pada satu pihak, dan satu orang atau lebih sebagai pelepas uang (geldschieter) pada pihak yang lain. Adapun dasar pemikiran dari pembentukan perseroan ini ialah seorang atau lebih mempercayakan uang atau barang untuk

${ }^{8}$ Kansil, Pokok-Pokok Pengetahuan Hukum Dagang Indonesia, (Jakarta: Sinar Grafika, 2002), h. 76-77. 
digunakan didalam perniagaan atau lain perusahaan kepada seorang lainnya atau lebih yang menjalankan perusahaan tersebut, dank arena itulah orang yang menjalankan perusahaan itu sajalah yang pada umumnya berhubungan dengan pihak-pihak ketiga. Karena itu pula pengusaha bertanggung jawab sepenuhnya terhadap pihak ketiga, dan tidak semua anggotany yang bertindak keluar. Dan demikian maksud KUHD itu adalah suatu perseroan yang tidak bertindak umum. Didalam perseroan ini seorang atau lebih dari anggotaanggotanya (si pemberi uang) tidak menjadi pimpinan perusahaan maupun bertidak terhadap pihak ketiga. ${ }^{9}$

d) Perseroan Terbatas

Perseroan Terbatas, yang selanjutnya disebut perseroan , adalah juga badan hukum yang merupakan persekutuan modal, didirikan berdasarkan perjanjian, melakukan kegiatan usaha dengan modal dasar yang seluruhnya terbagi dalam saham dan memenuhi persyaratan yang ditetapkan dalam undang-undang ini serta peraturan pelaksanaannya. ${ }^{10}$

\section{B. Perseroan Terbatas}

\section{Perseroan Terbatas Sebagai Subjek Hukum}

Secara teoritis tampaknya tidaklah menjadi masalah bila dikemukan bahwa PT sebagai subjek hukum. Artinya, dalam tataran teoritis dapat dijelaskan bahwa dengan PT sebagai subjek hukum berarti ia mempunyai kapasitas hukum (legal standing) untuk hadir didepan pengadilan dalam hal ia menggugat dan digugat oleh pihak lain. Namun dalam tataran praktis, hal ini agak sulit untuk diwujudkan. Disebut demikian sebab PT sebagai badan

\footnotetext{
${ }^{9}$ Ibid., h. $84-85$

${ }^{10}$ Pasal 1 butir (1) Undang-Undang Nomor 40 Tahun 2007 tentang Perseroan Terbatas
} 
hukum pada dasarnya adalah suatu kreasi hukum. Artinya PT sebagai pembawa hak dan kewajiban sesuatu yang abstrak. ${ }^{11}$

\section{Pengertian Perseroan Terbatas}

Perseroan Terbatas (PT) adalah badan hukum yang berarti perseroan merupakan subjek hukum dimana perseroan sebagai sebuah badan yang dapat dibebani hak dan kewajiban seperti halnya manusia pada umumnya. Oleh karena itu sebagai badan hukum, perseroan terbatas mempunyai kekayaan sendiri yang terpisah dengan kekayaan pengurusnya. Dalam melakukan kegiatan yang dilihat jangan perbuatan pengurusnya atau pejabatnya, tetapi yang harus dilihat adalah perseroannya, karena yang bertanggung jawab adalah perseroan. Kemudian disebutkan pula perseroan didirikan berdasarkan perjanjian, hal ini menunjukkan sebagai suatu perkumpulan dari orang-orang yang bersepakat mendirikan sebuah badan usaha yang berbentuk perseroan terbatas. Berhubung dasarnya menggunakan perjanjian, maka tidak dapat dilepaskan dari syarat-syarat yang ditetapkan pasal 1320 KUH Perdata dan asas-asas perjanjian lainnya. ${ }^{12}$

\section{Pengaturan Perseroan Terbatas di Indonesia}

Pengaturan mengenai Perseroan Terbatas (PT) di Indonesia sudah dikenal sejak zaman pendudukan belanda dengan nam Naamloze Venootschap (disingkat NV). NV diatur dalam kitab undang-undang hukum dagang (KUHD), khusus pada buku pertama, titel ketiga, bagian ketiga tentang perseroan terbatas serta terdiri dari 20 pasal (pasal 36-35). Pada Tahun 1995 pengaturan mengenai PT dalam KUHD digantikan dengan Undang-undang Nomor 1 Tahun 1995 Tentang Perseroan Terbatas. Alasan penggantian pengaturan mengenai PT dalam KUHD ke UU No.1/1995, seperti dicantumkan dalam konsideransnya karena

${ }^{11}$ Sentosa Sembiring, Hukum Perusahaan Tentang Perseroan Terbatas, (Bandung: Nuansa Aulia, 2006), h. 33,

${ }^{12}$ Gatot Supramono, Hukum Perseroan Terbatas, (Jakarta: Djambatan, 2007), h. 2-3. 
ketentuan PT dalam KUHD dianggap tidak sesuai dengan perkembangan ekonomi dan dunia usaha dam menciptakan kesatuan hukum perseroan yang berbentu badan hukum.

Undang-undang PT No. 1/1995 bertahan selama 15 tahun sampai kemudian diganti dengan Undang-undang Nomor 40 Tahun 2007 tentang Perseroan Terbatas. UUPT 2007 menambahkan beberapa hal yang belum diatur sebelumnya dalam UUPT 1995, termasuk didalamnya mengenai klasifikasi PT yang terdiri dari: ${ }^{13}$

a. Perseroan Tertutup

b. Perseroan publik, harus memenuhi kriteria jumlah pemegang saham dan modal disetor sesuai ketentuan

c. Perseroan terbuka, yaitu perseroan public atau perseroan yang melakukan penawaran umum saham.

\section{Tanggung Jawab Sosial Perusahaan}

\section{Pengertian Tanggung Jawab Sosial Perusahaan}

Tanggung Jawab Sosial Perusahaan atau Corporate Social Responsibility (CSR) adalah sebuah kebutuhan bagi korporat untuk dapat berinteraksi dengan komunitas local sebagai bentuk masyarakat secara keseluruhan. Kebutuhan koporat untuk beradaptasi dan guna mendapatkan keuntungan sosial dari hubungannya dengan komunitas local, sebuah keuntungan sosial berupa kepercayaan (trust). Tanggung Jawab Sosial Perusahaan tentunya sangat berkaitan dengan kebudayaan perusahaan dan etika bisnis yang harus dimiliki oleh budaya perusahaan, karena untuk melaksanakan Tanggung Jawab Sosial Perusahaan diperlukan suatu budaya yang didasari oleh etika yang bersifat adaptif. Dalam arti lain, Tanggung Jawab Sosial Perusahaan merupakan suatu komitmen berkelanjutan dari dunia usaha untuk

${ }^{13}$ Pasal 1 angka 7 UUPT Nomor 40 Tahun 2007 tentang Perseroan Terbatas jo Pasal 1 angka 22 Undang-Undang Nomor 8 Tahun 1995 Tentang Pasar Modal 
bertindak etis dan memberikan kontribusi kepada pengembangan ekonomi dari komunitas setempat ataupun masyarakat luas. Apabila kita melihat dan menyimak dari definisi Tanggung Jawab Sosial Perusahaan berarti salah satu unsurnya adalah pemberdayaan masyarakat dan kemiskinan yang akan diuraikan selanjutnya. $^{14}$

Seperti pembangunan berkelanjutan, Tanggung Jawab Sosial Perusahaaan juga luas, sebagai konsep dialektik. Dalam istilah yang paling umum, Tanggung Jawab Sosial Perusahaan berkaitan dengan peran bisnis dalam masyarakat. Premis dasarnya adalah bahwa menajer perusahaan memiliki kewajiban etis untuk mempertimbangkan dan menjawab kebutuhan masyarakat, bukan hanya bertindak semata-mata demi pemegang saham atau kepentingan diri mereka. Dalam banyak hal, Tanggung Jawab Sosial Perusahaan dapat dianggap menimbulkan perdebatan dan bukan apakah menajer perusahaan memiliki kewajiban untuk mempertimbangkan kebutuhan masyarakat, tetapi sejauh mana mereka harus benar-benar peduli dalam mempertimbangkan kebutuhan masyarakat sekitarnya. ${ }^{15}$

\section{Tanggung Jawab Sosial dan Pembangunan Nasional}

Pembangunan nasional pada dasarnya tidak hanya tanggung jawab pemerintah untuk melaksanakannya, tetapi juga anggota masyarakat dan juga pihak swasta yang berwujud korporat untuk terlihat langsung maupun tidak langsung dalam usaha pengembangan masyarakat. Menurut Undang-undang Perseroan Terbatas No.40 Tahun 2007 pasal 74 ayat 1 menyebutkan bahwa perseroan terbatas yang menjalankan usaha dibidang dan/atau bersangkutan dengan sumber daya alam wajib menjalankan tanggung jawab sosial dan lingkungan. Kemudian pada Undang-

\footnotetext{
${ }^{14}$ Budi Untung, CSR Dalam Dunia Bisnis, (Yogyakarta:Andi Offset, 2014), h. 3

${ }^{15}$ Ibid, h. $35-36$
} 
undang No 25 tahun 2007 pasal 15 (b) menyatakan bahwa setiap penanaman modal berkewajiban melaksanakan tanggung jawab sosial korporat. Dalam hal ini dimaknai sebagai Tanggung Jawab Sosial yang mengarah pada pengembangan masyarakat lokal sekitar korporat itu berdiri. Sedangkan pemerintah baik pusat maupun daerah menyediakan perangkat peraturannya sebagai regulator dalam hubungan antara masyarakat, swasta dan pemerintah. ${ }^{16}$

Untuk memahami pelaksanaan CSR di Indonesia, sebaiknya berangkat dari perkembangan pemahaman CSR terlebih dahulu. CSR berkembang pada akhir tahun 90 an dengan ditandainya munculnya definisi CSR oleh WBSD (Worl Business Counsil for Sustainable Development) tahun 1995, sebuah lembaga forum forum bisnis yang digagas oleh badan Perserikatan Bangsa Bangsa untuk kalangan bisnis agar dapat berkontribusi dalam pembangunan. Konteks saat itu adalah pembangunan berkelanjutan (Sustainable Development), suatu konsep pembangunan demi masa tanpa merusak sumber daya alam, dimana menyatukan 3 elemen pembangunan yaitu ekonomi, lingkungan dan sosial. ${ }^{17}$

Ruang lingkup CSR sendiri yang dikembangkan oleh WBSD pada awalnya adalah keluarga para pekerja dalam lingkaran korporat terlebih dahulu kemudian ke masyarakat yang ada disekitarnya. Focus aktifitas kepada kegiatan ekonomi yang meningkatkan kualitas hidup masyarakatnya. Definisi dan konsep inilah kemudian yang yang banyak dianut dan menjadi dasar oleh banyak korporat dan para akademisi, baik akademisi manajemen dan social science sampai sekarang. ${ }^{18}$

\footnotetext{
${ }^{16}$ Bambang Rudito \& Melia Famiola, CSR, (Bandung: Rekayasa Sains, 2013), h. 12

${ }^{17}$ Ibid., h. 12

${ }^{18}$ Ibid., h. 14
} 
Pelaksanaan CSR kemudian berkembang tanpa pedoman yang jelas, kerena memang tidak ada standar yang jelas. Banyak korporat yang kemudian melaksanakan CSR sesuai dengan focus dan sumber daya yang ada, kemudian berkembanglah kerancuan tentang CSR. Misalnya penyamaan konsep CSR dengan Community Development (Pengembangan Masyarakat) atau CSR dengan kegiatan Philantrophy (charity atau dengan kata lain "bagibagi uang).

Berkembang juga dengan berbagai debat tentang CSR. Seperti misalnya karangan para Maexian kaum anti kapitalis, yang banyak dianut oleh kalangan Non Government Organization (NGO), yang pesimis dan apatis terhadap perkembangan CSR. CSR dilihat sebagai alat pembenaran dominasi kapitalis terhadap masyarakat.dengan sudah melakukan CSR maka dunia usaha dapat menyembunyikan praktek-praktek tidak benarnya. Praxis ini didukung oleh kenyataan semakin banyaknya korporat yang merusak hutan dan lingkungan di Kalimantan, Sumatra, Papua dengan kemudian membarikan suara bahwa mereka telah mendonasikan uangnya untuk CSR. Dalam konteks ini sesungguhnya praktek CSR hanya sebagai kedok untuk menutupi kebusukan-kebusukan yang dilakukannya.

Pemahaman tentang CSR sesungguhnya adalah sebagai suatu komitmen korporat yang dituangkan dalam pedoman bagi korporat dalam bekerja sesuai dengan aturan yang berlaku untuk ikut berkontribusi dalam pembangunan, mensejahterakan masyarakat yang ada di sekitarnya. Lingkup kerja CSR tetap dimulai dari lingkungan internal terlebih dahulu, memastikan semua komponen dalam corporat mematuhi dan memahami etika tata aturan yang berlaku, kemudian para stakeholder yang ada diluar korporat. Hal ini sesuai dengan definisi yang dibangun oleh ISO 26000 , sebagai berikut "Responsibility of an organization for the 
impact of its decisions and activities on society and the environment, through transparent and ethical behavior that contributes to sustainable development, health and the welfare of the society, takes into account the expectations of stakeholders; is in compliance with applicable law and konsistent with international norms of behavior in its relationship" (2010). ${ }^{19}$

Kuncinya adalah bahwa kegiatan CSR adalah komitmen dan tanggung jawab korporat, baik yang bersifat sosial maupun lingkungan serta usaha bagi korporat untuk beradaptasi dengan lingkungan sosial masyarakat. Untuk itu, mereka harus bertanggung jawab ikut menjaganya. Oleh karena standard an ukuran yang jelas lebih dibutuhkan untuk meningkatkan kualitas program dan kadar tanggung jawab korporat sendiri. ${ }^{20}$

\section{Bentuk-bentuk Tanggung Jawab Sosial Perusahaan Dalam Suatu Perusahaan}

Penjabaran dari kepedulian sosial dari suatu bisnis berbentuk pelaksanaan tanggung jawab sosial bisnis. Itu dapat dilihat bahwa semakin tinggi tingkat kepedulian sosial suatu bisnid maka semakin meningkat pula pelaksanaan praktek bisnis etik dalam masyarakat. Beberapa bentuk pelaksanaan tanggung jawab sosial perusahaan yang dapat kita temui di Indonesia adalah sebagai berikut:

a. Pelaksanaan Hubungan Industrial Pancasila (HIP). Kesepakatan Kerja Bersama (KKB) merupakan bentuk pelaksanaan yang telah banyak dijalankan pengusaha dengan karyawannya dan dituangkan dalam buku. Dimana diatur kewajiban dan hak masing-masing pihak.

\footnotetext{
${ }^{19}$ Ibid., h. 15

${ }^{20}$ Ibid h. 15
} 
b. Analisis mengenai Dampak Lingkungan (AMDAL). Penanganan limbah industry sebagai bagian dari produksi sebagai bentuk partisipasi menjaga lingkungan.

c. Penerapan prinsip kesehatan dan keselamatan kerja (k3). Penekanan pada faktor keselamatan pekerja dengan mempergunakan alat-alat yang berfungsi menjaga keselamatan seperti topi pengaman, masker pelindung maupun lainnya.

\section{PEMBAHASAN}

\section{Pelaksanaan Tanggung Jawab Sosial Dalam Kerangka UUPT di Indonesia}

Sebagai sebuah konsep yang baru dimasukkan kedalam undangundang PT, pemerintah diharapkan tidak salah dalam menafsirkan konsep CSR ini. Kontroversi yang terjadi dikalangan pengusaha sejak diwajibkannya pelaksanaan CSR bagi sebuah PT adalah Karena ketidakpahaman sejumlah kalangan pengusaha dalam mengartikan CSR dan adanya ketakutan bahwa pemerintah juga salah tafsir sehingga pada akhirnya perusahaan akan dirugikan melalui kewajiban pelaksanaan CSR ini. Salah satu hal yang terutama dikhawatirkan adalah bahwa CSR ini menjadi philanthropy wajib dengan bagian persentase yang dikaitkan dengan pengeluaran (spending) dengan tanpa memperhatikan (profit) dan atau kesanggupan perseroan, ini yang terjadi maka CSR akan menjadi bencana besar bagi dunia usaha dan masyarakat konsumen. CSR yang demikian tidak hanya merugikan kepentingan pengusaha tetapi juga seluruh stakeholders perusahaan, khususnya masyarakat banyak sebagai konsumen. Ini benar-benar bertolak belakang dengan konsep CSR yang sesungguhnya. ${ }^{21}$

Bunyi pasal 74 Undang-undang Nomor 40 Tahun 2007 Tentang PT yang mewajibkan CSR bagi PT adalah: ${ }^{22}$

\footnotetext{
${ }^{21}$ Gunawan \& Yeremia Ardi Pratama, Risiko Hukum \& Bisnis Perusahaan Tanpa CSR, (Jakarta: Percetakan Penebar Swadaya, 2008)

${ }^{22}$ Pasal 74 Undang-undang Nomor 40 Tahun 2007 Tentang Perseroan Terbatas
} 
(1) Perseroan yang menjalankan kegiatan usahanya dibidang dan/atau berkaitan dengan sumber daya alam wajib melaksanakan Tanggung Jawab Sosial dan Lingkungan.

(2) Tanggung Jawab Sosial dan Lingkungan sebagaimana dimaksud pada ayat (1) merupakan kewajiban Perseroan yang dianggarkan dan diperhitungkan sebagai biaya Perseroan yang pelaksanaannya dilakukan dengan memperthatikan kepatutan dan kewajaran

(3) Perseroan yang tidak melaksanakan kewajiban sebagaimana dimaksud pada ayat (1) dikenai sanksi sesuai dengan ketentuan peraturan perundang-undangan.

(4) Ketentuan lebih lanjut mengenai Tanggung Jawab Sosial dan Lingkungan diatur dengan Peraturan Pemerintah.

Rumusan pasal 74 Undang-undang Nomor 40 Tahun 2007 tentang PT tersebut dapat dijabarkan sebagai berikut:

1. Pasal 74 ayat (1) UUPT : Perseroan yang menjalankan kegiatan usahanya dibidang dan/atau berkaitan dengan sumber daya alam wajib melaksanakan Tanggung Jawab Sosial dan Lingkungan.

Dalam pasal 74 ayat (1) UUPT ini disebutkan bahwa:

"Yang dimaksud dengan "Perseroan yang menjalankan kegiatan usahanya dibidang sumber daya alam "adalah Perseroan yang kegiatan usahanya mengelola dan memanfaatkan sumber daya alam $^{, 23}$

"Yang dimaksud dengan "Perseroan yang menjalankan kegiatan usahanya yang berkaitan dengan sumber daya alam" adalah perseroan yang tidak mengelola dan tidak memanfaatkan sumber daya alam, tetapi kegiatan usahanya berdampak pada fungsi kemampuan sumber daya alam"24

Dalam penjelasan Pasal 74 tersebut jelas disebutkan bahwa kewajiban pelaksanaan CSR bagi perusahaan yang menjalankan kegiatan

\footnotetext{
${ }^{23}$ Penjelasan Pasal 74 Undang-undang No.40 Tahun 2007 Tentang Perseroan Terbatas

${ }^{24}$ Ibid
} 
usahanya dibidang dan/atau berkaitan dengan sumber daya alam ini tidak hanya melihat pada bisnis inti (core business) dari perusahaan tersebut. Walaupun perusahaan tersebut tidak secara langsung melakukan eksploitasi sumber daya alam, tetapi selama kegiatan usahanya berdampak pada fungsi kemampuan sumber daya alam, maka perusahaan tersebut wajib melaksanakan tanggung jawab sosialnya. Hal ini berarti bahwa baik itu perusahaan pertambangan, industri perkayuan, industry makanan, yang dalam kegiatan usahanya berhubungan langsung dengan sumber-sumber daya alam, maupun rumah sakit, perusahaan telekomunikasi, perbankan, percetakan dan perusahaan-perusahaan lain yang walaupun tidak secara langsung menggunakan sumber daya alam dalam kegiatan usahanya, wajib melaksanakan CSR. ${ }^{25}$

Dengan demikian jelaslah bahwa konsep CSR yang semula hanya merupakan kewajiban moral, dengan berlakunya Pasal 74 ayat (1) UUPT menjadi kewajiban yang dapat dipertanggungjawabkan dalam hukum, tetapi khusus hanya bagi perseroan yang menjalankan kegiatan usahanya dibidang dan/atau berkaitan dengan sumber daya alam. Bagi perseroan lainnya, CSR hanya merupakan kewajiban moral saja. ${ }^{26}$

Pasal 74 ayat (2) UUPT: Tanggung Jawab Sosial dan Lingkungan sebagaimana dimaksud pada ayat (1) merupakan kewajiban perseroan yang dianggarkan dan diperhitungkan sebagain biaya perseroan yang pelaksanaannya dilakukan dengan memperhatikan kepatutan dan kewajaran.

Dalam ayat ini disebutkan bahwa biaya CSR diperhitungkan sebagai salah satu komponen biaya perusahaan. Biaya yang dikeluarkan untuk melaksanakan CSR ini seharusnya pada akhir tahun buku diperhitungkan sebagai salah satu pengeluaran perusahaan. Seperti telah disinggung sebelumnya, agar dapat dijadikan sebagai biaya pengurangan penghasilan kena pajak, maka rencana kegiatan Tanggung Jawab Sosial

\footnotetext{
${ }^{25}$ Ibid., h. 95

${ }^{26}$ Ibid., h. 95
} 
dan lingkungan yang akan dilaksanakan dan anggaran yang dibutuhkan wajib untuk dimuat atau dimasukkan kedalam rencana kerja tahunan.

Selain itu dengan memperhatikan ketentuan pajak yang berlaku biaya CSR haruslah merupakan biaya yang dikeluarkan perseroan untuk mendapatkan, menagih, dan memelihara penghasilan. Jadi jelaslah biaya CSR bukanlah philanthropy.

Hal ini tidak berarti keuntungan perusahaan setelah pajak, dipotong lagi untuk kewajiban pelaksanaan CSR. Jadi, biaya pelaksanaan CSR seharusnya tidak menjadi "pajak" tambahan bagi perseroan. Keuntungan bersih perusahaan setelah dipotong untuk dana cadangan perusahaan adalah hak sepenuhnya dari para pemegang saham. Jadi tidak dapat digunakan untuk biaya pelaksanaan CSR.

Seperti telah disebutkan sebelumnya bahwa pelaksanaan CSR bukan hanya menjadi tanggungan dari pemegang saham. Mengenai nantinya keuntungan perusahaan tersebut dipakai oleh pemegang saham yang bersangkutan baik atas nama pribadi maupun atas nama PT untuk melakukan kegiatan sosial, itu adalah kegiatan philanthropy, dan itu bukan CSR.

Mengenai besarnya anggaran CSR ini jelas disebutkan bahwa pelaksanaannya dilakukan dengan memperhatikan kepatutan dan kewajaran, yaitu dengan pengertian bahwa biaya-biaya tersebut harus diatur besarnya sesuai dengan manfaat yang hendak dituju dari pelaksanaan CSR itu sendiri berdasarkan kemampuan keuangan perseroan dan potensi resiko dan besarnya tanggung jawab yang harus ditanggung oleh perseroan sesuai dengan kegiatan usahanya tersebut. ${ }^{27}$

Kondisi tersebut pada dasarnya hendak memperhatikan bahwa penentuan besar kecilnya dana yang mereka anggarkan untuk

\footnotetext{
${ }^{27}$ Ibid., h.97
} 
pelaksanaan CSR dengan tetap memperhatikan tujuan pelaksanaan CSR yaitu sustainability perusahaan, lingkungan dan sosial. ${ }^{28}$

Pasal 34 ayat (3) UUPT : Perseroan yang tidak melaksanakan kewajiban sebagaiman dimaksud pada ayat (1) dikenai sanksi sesuai dengan ketentuan peraturan perundang-undangan. Penjelasan ayat (3) pasal 74 UU No.40 Tahun 2007 Tentang PT menyatakan bahwa:

"Yang dimaksud dengan "dikenai sanksi sesuai dengan ketentuan peraturan perundang-undangan" adalah dikenai segala bentuk sanksi yang diatur dalam peraturan perundang-undangan yang terkait"

Penjelasan pasal 74 ayat (3) UU No.40 Tahun 2007 tersebut secara jelas menyatakan bahwa sanksi yang dikenakan bagi perseroan yang melanggar ketentuan mengenai Tanggung Jawab sosial ini adalah sanksi yang dikenakan bukan sanksi karena perusahaan tidak melakukan CSR menurut Undang-undang Perseroan Terbatas, melainkan sanksi yang karena perusahaan mengabaikan CSR sehingga perusahaan itu melanggar aturan-aturan terkait dibidang sosial dan lingkungan yang berlaku. ${ }^{29}$

Misalnya suatu perusahaan industri yang menghasilkan limbah berupa senyawa kimian yang berbahaya, yang berdasarkan UU No. 23 Tahun 1997 tentang Pengelolaan lingkungan hidup diwajibkan untuk melakukan pengelolaan dan pengolahan limbah tersebut terlebih dahulu sebelum pembuangannya dilakukan, dengan memperhatikan dan memenuhi berbagai persyaratan yang telah ditetapkan dalam pemberian izinnya. Ternyata lalai atau tidak memenuhi kewajiban yang dipersyaratkan tersebut. Pelanggaran terhadap hal tersebut, meskipun termasuk dalam pelanggaran CSR namun dikenakan sanksi pidana dan administrative menurut UU No.23 Tahun 1997 tersebut. ${ }^{30}$

${ }^{28}$ Yeremia Ardi Pratama, Resiko Hukum Dan Bisnis Perusahaan Tanpa CSR, (Jakarta, 2008), h. 93-98

\footnotetext{
${ }^{29}$ Ibid., h. 98

${ }^{30}$ Ibid., h. 99
} 
74 ayat (4) UUPT : Ketentuan lebih lanjut mengenai Tanggung Jawab Sosial dan Lingkungan diatur dengan Peraturan Pemerintah. Ketentuan yang disebutkan dalam ayat (1), (2) dan (3) pasal 74 UU No. 40 Tahun 2007 adalah peraturan yang memayungi pelaksanaan CSR di Indonesia. Dengan demikian sesuai dengan amanah yang diberikan oleh Undang-undang Perseroan Terbatas tersebut, Pemerintah perlu membuat aturan pelaksanaannya dalam bentuk pemerintah. Dalam membuat peraturan pemerintah ini, pemerintah diharapkan tidak salah menafsirkan CSR sehingga aturan yang dibuat nantinya justru memberatkan perusahaan dan akan menghilangkan maksna dari CSR itu sendiri. Dengan dimasukannya CSR dalam UU No.40 Tahun 40 Tahun 2007 tentang Perseroan Terbatas, CSR yang pada awalnya muncul Karena kesadaran perusahaan dan lebih merupakan moral liability, menjadi legal liability, walaupun sanksi yang diterima oleh perusahaan adalah UU terkait. ${ }^{31}$

Konsep CSR dalam UU No.40 Tahun 2007 Tentang PT menimbulkan konsekuensi bagi PT, yaitu: ${ }^{32}$

1. PT harus memiliki corporate identity

Sebelum melaksanakan kegiatan CSR nya perusahaan harus mampu mengidentifitaskan dirinya melalui visi, misi dan nilainilai perusahaan serta menempatkan dirinya dalam posisi yang tpat ditengah komunitas dan lingkungannya.

2. PT harus mampu merumuskan kegiatan CSR nya dengan memperhatikan hal-hal sebagai berikut:

a. CSR bukanlah kegiatan philanthropy

b. Pelaksanaan CSR memerlukan keterlibatan dari semua stakeholders

c. Pelaksanaan CSR menuntut keterlibatan aktif perusahaan

\footnotetext{
31 Ibid., h. 100

${ }^{32}$ Ibid, h. 101-106
} 
d. Tujuan pelaksanaan CSR adalah sustainability perusahaan, lingkungan dan sosial

e. Pelaksanaan CSR disesuaikan dengan kemampuan perusahaan dan khususnya

f. Peraturan-peraturan perundang-undangan yang berlaku di Indonesia yang berhubungan dengan masalah ekonomi, sosial dan lingkungan, antara lain:

1) UU No.11 Tahun 1967 tentang ketentuan-ketentuan pokok pertambangan khususnya aturan mengenai penggolongan bahan-bahan galian, kuasa pertambangan, hubungan antara kuasa pertambangan dengan hak-hak atas tanah dan segala aturan lainnya yang terkait dengan masalah pertambangan.

2) UU No. 23 Tahun 1997 Tentang pengelolaan lingkungan hidup khususnya mengenai pelestarian fungsi lingkungan hidup.

3) UU No. 5 Tahun 1999 tentang larangan praktik monopoli dan persaingan usaha tidak sehat khususnya mengenai perjanjian dan kegiatan yang dilarang.

4) UU No. 8 Tahun 1999 Tentang perlindungan konsumen, khususnya mengenai hak-hak konsumen.

5) UU No. 39 Tahun 1999 Tentang hak asasi manusia khususnya mengenai hak asasi manusia dan kebebasan dasar manusia yang termasuk didalamnya hak-hak pekerja wanita dan anakanak

6) UU No.41 Tahun 1999 Tentang kehutanan khususnya mengenai pengelolaan hutan yang termasuk didalamnya tata hutan dan penyusunan rencana pengelolaan, pemanfaatan hutan, dan penggunaan kawasan hutan, perizinan usaha kehutanan, perlindungan hutan dan konservasi alam.

7) UU No. 20 Tahun 2001 Tentang perubahan atas UU No. 31 Tahun 1999 Tentang pemberantasan Tindak Pidana Korupsi khususnya mengenai masalah bribery (penyuapan) 
8) UU No. 19 Tahun 2003 Tentang badan usaha milik Negara. Pelaksanaan CSR juga berlaku bagi BUMN yang mengacu pada UU ini.

9) UU No.7 Tahun 2004 Tentang Sumber Daya Air khususnya mengenai pengelolaan sumber daya air, pola pengelolaan sumber daya air, rencana pengelolaan sumber daya air, hak guna air, hak guna pakai air, hak guna usaha air dan aturan lainnya yang terkait dengan sumber daya air.

10)Dan peraturan perundang-undangan terkait lainnya, sesuai dengan industri terkait.

Agar memudahkan memahami regulasi Tanggung Jawab Sosial Perusahaan dan mampu menerapkannya sesuai jenis, cakupan, dan kebutuhan perusahaan. Peneliti memaparkan ke 7 (tujuh) regulasi Tanggung Jawab Sosial Perusahaan di Indonesia, jika sudah memahami, pihak perusahaan diharapkan bisa merujuk pada aturan mana yang mengikatnya, selain juga menjadi kontrol bagi pihak lain yang akan menjadikan tanggung jawab sosial perusahaan sebagai alat kepentingan kalangan tertentu. Adapun ke 7 (tujuh) regulasi terkait tanggung jawab sosial perusahaan di Indonesia sebagai berikut:

1. Peraturan BUMN, sebagaimana keputusan mentri BUMN Per05/MBU/2007 tentang program kemitraan bina lingkungan (PKBL). PKBL terdiri dari program perkuatan usaha kecil melalui pemberian pinjaman dana bergulir dan pendampingan (disebut program kemitraan), serta program pemberdayaan kondisi sosial masyarakat sekitar (disebut program bina lingkungan), dengan dana kegiatan yang bersumber dari laba BUMN.

2. Peraturan mengikat perseroan terbatas (PT) yang operasionalnya terkait SDA, yaitu undang-undang Perseroan Terbatas Nomor 40 Tahun 2007.

3. Peraturan Pemerintah (PP) Nomor 47 Tahun 2012 Tentang tanggung jawab sosial dan lingkungan. 
4. Peraturan yang mengikat jenis perusahaan penanaman modal, yaitu Undang-undang Nomor 25 Tahun 2007 tentang Penanaman Modal. Dalam pasal 15 (b) dinyatakan bahwa "setiap penanaman modal wajib melaksanakan tanggung jawab sosial perusahaan”. Dan sanksiOsanksinya diatur dalam pasal 34 berupa sanksi administrative dan sanksi lainnya.

5. Peraturan tanggung jawab sosial perusahaan pengelola minyak dan gas (Migas), diatur dalam Undang-undang minyak dan gas Bumi nomor 22 tahun 2001

6. Undang-undang nomor 13 Tahun 2011 tentang penanganan fakir miskin.

7. Peraturan Mntri Sosial RI Nomor 13 Tahun 2012 tentang forum tanggung jawab dunia usaha dalam penyelenggaraan kesejahteraan sosial.

\section{KESIMPULAN}

Kesimpulan adalah pernyataan singkat, jelas, dan sistematis dari keseluruhan hasil analisis, pembahasan, dan pengujian hipotesis dalam sebuah penelitian. Peneliti berusaha memperlihatkan benang merah antara keseluruhan bagian dalam penelitian, terutama antara masalah penelitian, hipotesis, dan analisis data. Sebuah kesimpulan ilmiah harus didasarkan pada hasil penelitian. Dan dari hasil penelitian yang penulis lakukan yang berjudul "Pelaksanaan Tanggung Jawab Sosial Perusahaan Pada PT. HKL di Tinjau Dari Undang-Undang Nomor 40 Tahun 2007 Tentang Perseroan Terbatas" dapat di ambil kesimpulan sebagai berikut:

1. Pelaksanaan Tanggung Jawab Sosial Perusahaan pada PT. HKL di Desa Sungai Pinang, Desa Balam Jaya dan Desa Kuapan, Kecamatan Tambang Kabupaten Kampar dapat dikatakan di laksanakan dalam bentuk pemberian bantuan Dana seuai dengan permohonan proposal yang diberikan oleh masyarakat di Desa sekitar perusahaan itu melakukan kegiatan Industri, dan bentuk lain 
yang diberikan oleh pihak PT. HKL adalah bantuan dalam bentuk Barang, dan berdasarkan hasil wawancara yang penulis lakukan dilapangan dengan perwakilan dari PT. HKL yang mengatakan bahwa "Dalam proses penyaluran dana Bantuan Sosial atau Tanggung Jawab Sosial Perusahaan, pihak PT. HKL tidak ikut berpartisipasi secara langsung, mereka hanya berpartisipasi dengan cara memberikan bantuan dana ataupun barang yang menjadi kebutuhan masyarakat". Dan berdasarkan hasil wawancara yang penulis dapatkan dari perwakilan Masyarakat setempat yang mengatakan bahwa: "Bentuk Tanggung Jawab Sosial Perusahaan yang diberikan oleh PT. HKL kepada masyarakat belum sesuai dengan apa yang dibutuhkan oleh masyarakat itu sendiri, bantuan-bantuan yang diberikan selama ini hanya sebagai syarat saja agar citra perusahaan tersebut tetap eksis di masyarakat, dan bantuan yang diberikan juga tidak berdampak kepada perkembangan masyarakat di sekitar perusahaan itu berdiri, baik itu dari segi pendidikan, kesehatan, Sosial, ataupun pembangunan infrastruktur. Dengan demikian maka penulis dapat menyimpulkan bahwa Tanggung Jawab Sosial Perusahaan yang menjadi kewajiban perusahaan untuk menyalurkannya kepada masyarakat belum terlaksana sesuai dengan Undang-Undang Nomor 40 Tahun 2007 dimana yang dimaksud dengan tanggung jawab sosial perusahaan adalah komitmen perseroan untuk berperan serta dalam pembangunan ekonomi berkelanjutan guna meningkatkan kualitas kehidupan dan lingkungan yang bermanfaat, baik bagi perseroan sendiri, komunitas satempat, maupun masyarakat dalam umumnya dan mengenai bentuk pelaksanaannya terdapat pada Peraturan Daerah Provinsi Riau Nomor 6 Tahun 2012 tentang Tanggung Jawab Sosial Perusahaan di Provinsi Riau yang mengatakan bahwa: Bidang kerja Tanggung Jawab Sosial Perusahaan seperti Dunia 
Pendidikan, Kesehatan, Infrastruktur, Sosial Keagamaan, perekonomian masyarakat dan juga pemberdayaan masyarakat adat dan pelestarian lingkungan juga belum terlaksana sesuai peraturan yang telah ditetapkan.

2. Hambatan yang di alami oleh PT. HKL dalam menyalurkan Tanggung Jawab Sosial Perusahaan adalah lambatnya proses persetujuan proposal yang diajukan masyarakat, karna harus menunggu persetujuan dari tim direksi perusahaan, Turunnya hasil produksi perusahaan yang berdampak kepada keuntungan yang didapatkan perusahaan yang tentu nya juga berpengaruh kepada pemberian Tanggung Jawab Sosial Perusahaan, dan PT. HKL Tidak Memiliki SDM Dibidang Tanggung Jawab Sosial Perusahaan.

\section{SARAN}

Berkenaan dengan uraian dan kesimpulan di atas, penulis memberikan saran sebagai berikut:

1. Pihak PT. HKL harus lebih memperhatikan kewajiban mereka di dalam penyaluran Tanggung Jawab Sosial Perusahaan di Desa sekitar perusahaan itu beroperasi, hal ini merupakan perhatian perusahaan dan sudah menjadi kewajiban yang harus di berikan kepada masyarakat setempat dimana perusahaan tersebut berada, karna dengan tindakan yang berhubungan dengan bantuanbantuan yang diberikan oleh perusahaan pastinya akan mempengaruhi kualitas kesejahteraan masyarakat yang berada di sekitarnya.

2. Kepada masyarakat setempat harus lebih aktiv untuk mempertanyakan haknya kepada PT. HKL agar perusahaan yang bersangkutan sadar bahwa mereka juga mempunyai tanggung jawab kepada masyarakat, dengan cara memberikan Tanggung Jawab Sosial Perusahaan yang dikeluarkan sebagian dari laba 
bersih perusahaan yang berpengaruh untuk pembangunan masyarakat di sekitarnya baik itu dalam bentuk pembangunan infrastruktur, kesehatan, pendidikan, kegiatan sosial dan keagamaan dan juga pelestarian lingkungan hidup.

\section{DAFTAR PUSTAKA}

Abdul Kadir Muhammad, 1993, Pengantar Hukum Perusahaan Indonesia, Bandung: Citra Aditya Bakti

Agus Sardjono, 2014, Pengantar Hukum Dagang, Jakarta: Raja Grafindo Persada

Aji, Desain Metode Penelitian Hukum Sosiologis, http://alisarjunip.blogspot.co.id/2013/06/tekhnik-sampling.html?m1, diakses pada tanggal 27 mei 2017

Amiruddin \& Zainal Asikin, 2003, Pengantar Metode Penelitian Hukum, Jakarta: Raja Grafindo Persada

Bambang Rudito \& Famiola Melia, 2013, CSR (Corporate Social Responsibility), Bandung: Rekayasa Sains.

Bambang Sunggono, 1996, Metodologi Penelitian Hukum, Jakarta: Raja Grafindo

Budi Untung, 2014, CSR Dalam Dunia Bisnis ,Yogyakarta: Andi Offset.

Faiz Manshur, CSR, Berangkat dari Falsafah Dasarnya, http:// faizmanshur.wordpress.com/2007/06/12/csr-berangkat-darifalsafah-dasarnya/, diakses pada tanggal 9 Maret 2017

Gatot Supramono, 2007, Hukum Perseroan Terbatas, Jakarta: Djambatan

Gunawan Widjaja \& Yeremia Ardi Pratama, 2008, Resiko Hukum \& Bisnis Perusahaan Tanpa CSR, Jakarta: Percetakan Penebar Swadaya.

Kansil dan Christine S.T. Kansil, 2001, Hukum Perusahaan Indonesia, Jakarta: Pradnya Paramita.

Kansil, 2002, Pokok-Pokok Pengetahuan Hukum Dagang Indonesia, Jakarta: Sinar Grafika.

Peraturan Daerah Provinsi Riau Nomor 6 Tahun Tanggung Jawab Sosial Perusahaan

Sentosa Sembiring, 2006, Hukum Perusahaan Tentang Perseroan Terbatas, Bandung: Nuansa Aulia

Undang-undang Nomor 40 Tahun 2007 Tentang Perseroan Terbatas.

Wikipedia, philanthropy, http://en.wikipedia.org/w/index.php? title= Philanthropy\&oldid=202385048diaksestanggal 9 maret 2008.

World Business Council For Sustainability Development, Corporate Sosial Responsibility: Meeting Changing Expectation.

Yahya Harahap, 2002, Hukum Perseroan Terbatas, Jakarta: Sinar Grafika ZaeniAsyhadie, 2011, Hukum Bisnis Prinsip Dan Pelaksanaannya di Indonesia, Jakarta: Raja Grafindo Persada. 